\title{
ENVIRONMENTAL PROTECTION AS FUNDAMENTAL RIGHT GUARANTEED TO THE EUROPEAN LEVEL
}

\author{
Alina Gentimir ${ }^{1}$ \\ ${ }^{1}$ Alexandru Ioan Cuza University, Faculty of Law, Iasi, ROMANIA, agentimir@yahoo.fr
}

Keywords: environment, protection, fundamental rights, Europe, Court, Convention

\begin{abstract}
The article examines, in a comparative perspective, both legal framework of the European Union and Council of Europe and case law of the Court of Justice of European Union and European Court of Human Rights in order to highlight superior level of the right to a healthy environment European protection. The multitude of concepts related to the environmental protection and their connections require compulsory conceptual delimitations. As other international and regional organizations, the European Union expresses interest in environmental protection, consecrating to it numerous legal instruments, the most relevant of these, in terms of human rights, being the Charter of Fundamental Rights, in which (Article 37) is provided expressly that environmental protection is a fundamental right, unlike the Council of Europe where this right is recognized only as an indirect right. Affiliation of this right to a certain category of rights - global rights, solidarity rights or individual or collective rights - has been a source of both doctrinal and jurisprudential disputes. Genuine interdependence with other fundamental rights such as the right to life, the right to private and family life, right to property and right to information ensues from the substance of the right to protection of the environment. The presentation of the principles which outline the content of the right in discussion emphasizes that the Charter text was drafted in accordance with the latest developments in the field of normative and jurisprudential environment established at international, regional and national levels, respectively, in interaction with the principle of sustainable development. Finally, an analysis of the most frequent modalities of environmental degradation contributes to find proper mechanisms for a better guarantee of the respect of environmental protection as a fundamental right.
\end{abstract}

\section{INTRODUCTION}

Nowadays, the humanity redefines its existence and its natural environment. Taking into considerations that the environment is the common heritage of human beings, it is recommended to be found progressive and polyvalent solutions for its protection and enrichment. 
Thanks to the different challenges as global warming or extension of the polluting industry, the policy of environmental protection has been restructured to be international and regional level in function of the fundamental goals and values which define the activity of the collective supranational and national entities. Being ones of the most important intergovernmental organizations in Europe, Council of Europe (Renuci, 2019, Sudre et al, 2019, Dutertre, 2004) and European Union (Chalmers et al, 2019; Lenaerts et al, 2014, Lenaert. et al, 2011), have established that the safeguard of the environment has to be one of the premises of its essential directions of action.

\section{CONCEPTUAL DELIMITATIONS}

The two concepts appeared in the domain of human rights in relation to environmental protection are "environmental law" and "right to a healthy environmental", the relationship between these two concepts being one of causation. The ambiguity of the definition of both concepts constitutes a permanent source of doctrinal and jurisprudential dispute (Rainey et al, 2019; Favoreu et al, 2015).

The first concept - environmental law - defines the scope of a branch of law that appeared in the $70 \mathrm{~s}$, and is configured by reference to its purpose: strict environmental protection. There is the preconception that environment brings together taking action to remove destruction and management of natural resources and eradication of pollution affecting the quality of people's lives (Andriantsimbazovina et al, 2008).

It is recommended to be noticed meaning differences between the notions of environment, nature and ecology. The concept of environment represents 'surrounding nature or space consisting of all external factors that are beings and things'. As well, it covers the 'set of external conditions, material and cultural elements that lives and develops an individual is human'. The concept of nature includes the 'surrounding physical world in all its manifestations diversity; all beings and things that existent'. The last concept - ecology - is defined as the "science that deals with the study of relationships between organisms and their environment, at the individual, population or community" (Andriantsimbazovina et al, 2008).

In order to be created the structure and domain of application of the environmental law are "borrowed concepts and methods of public law - easements, planning - or of private law - shared heritage - or economics - polluter pays principle - or biology - inventory" (Andriantsimbazovina et al, 2008).

Not less important, in order to obtain a complete covering of the environment phenomena it has to be taken into account the typology of environment. Thus, 
according to Articles 2-10 of the Lugano Convention (1996) ${ }^{1}$, environment abiotic and biotic features include "natural resources such as air, water, soil, fauna and flora, and the interaction between these factors and goods that make up the cultural heritage and the characteristics of the landscape".

\section{LEGAL FRAMEWORK}

In order to settle the right directions of the international and national actions, it has been written a legal framework related to the efficient policy against air and water pollution and protecting wildlife and natural resources savage. However, the reasoning of the norms depends on the situation which must be regulated and the level of regulation. Concrete domestic realities require specific measures which influence the limits of domestic legislation. Going further, Community texts develop and influence internal legislation. Therefore, "there is an evolution from a branch and technical approach (water, fauna, flora, forest, waste and toxic chemicals) to a global one" (Andriantsimbazovina et al, 2008).

Stockholm Declaration $(1972)^{2}$, Rio Declaration $(1992)^{3}$ or Lugano Convention (1993) $)^{4}$, Aarhus Convention $(1998)^{5}$, Declaration of Johannesburg (2002) ${ }^{6}$, Environmental Constitutional Charter (2004) ${ }^{7} 7$ are only few documents which shape the international legal framework.

1 The Convention on Civil Liability for Damage Resulting from Activities Dangerous to the Environment, or Lugano Convention, was adopted June 21, 1993 by Council of Europe

2 The Declaration of the United Nations Conference on the Human Environment, or Stockholm Declaration, was adopted June 16, 1972 by the United Nations Conference on the Human Environment

${ }^{3}$ The Rio Declaration on Environment and Development, or Rio Declaration, was adopted by United Nations "Conference on Environment and Development", informally known as the Earth Summit, held in Rio de Janeiro from 3 to 14 June in 1992.

4 The Convention on Civil Liability for Damage Resulting from Activities Dangerous to the Environment, or Lugano Convention, was adopted June 21, 1993 by Council of Europe

5 The UNECE Convention on Access to Information, Public Participation in Decision-making and Access to Justice in Environmental Matters, or Aarhus Convention, was signed on 25 June 1998 and entered into force on 30 October 2001. As of March 2014, it has 47 parties-46 states and the European Union.

${ }^{6}$ The Johannesburg Declaration on Sustainable Development, or Johannesburg Declaration, was adopted at the "World Summit on Sustainable Development" in September 2002

${ }^{7}$ The Environmental Constitutional Charter is the third branch of the French 1958 Constitution and has been incorporated by French Parliament alongside the 1789 Declaration of the Rights of Man and of the Citizen and the Declaration of Economic and Social Rights in the Preamble of the 1946 Constitution. 
Single Act of $1986^{8}$ provides in Article 174 that "Community policy on the environment shall contribute to objectives such as protecting and improving the environment, health protection".

Charter of Fundamental Rights ${ }^{9}$ as a setback in the context of a wide regulations speciale.

\section{LEGAL STATUS}

Doctrine (Renucci, 2019, Duterthe, 2004) underlines that there are views according to which the right to a healthy environment is not a right but an aspiration due to the fact that it defends, implicitly, universal values as the right to peace and development. The same general reasoning owed to the public interest which protects is proved, as well, by the imprecision of the right's structure. Precisely, the right to a healthy environment doesn't have indicated clearly its holders and its object. It may be found that its owners may be individuals, individual or association of environmental protection ${ }^{10}$. Consequently, it may be both an individual right or collective right, depending on the circumstances of its violation.

Just this equivocation founds its sui generis legal status, defined by its multiple qualifications: civil right, social right, solidarity right. So, it may be considered a complex right belonging to the first - political and civil rights, the second - social, cultural and economical rights and the third generation of rights solidarity rights.Being recognized only recently, majority of legal norms don't regulate it directly. That's why, firstly it has been indicated as indirect right, stablished by the judges through their decisions, through evolutionary interpretation,

as in matters of political - being element of the right to private life - and, then, social rights - being included in the domain of application of the right to healthy protection (Favoreu et al, 2015).

A fundamental landmark of a useful framing of the right to a healthy environment may be its inclusion in category of third generation rights, as solidarity right and right to the receivable, thanks to the collective interest which it serves, indisputable.

\footnotetext{
${ }^{8}$ The Single European Act was signed at Luxembourg on 17 February 1986, and at The Hague on 28 February 1986 and came into effect on 1 July 1987

${ }^{9}$ The Charter of Fundamental Rights of the European Union proclaimed on 7 December 2000 by the European Parliament, the Council of Ministers and the European Commission and did not have full legal effect until the entry into force of the Treaty of Lisbon on 1 December 2009.

${ }^{10}$ ECHR, Gorraiz Lizarraga and Others v. Spain, Application no. 62543/00, Judgment 27 April 2004
} 
As a fundamental individual right has procedural safeguards that have to be invoked in court if it is abused by public authorities and private individuals (Sudre et al, 2019).

The direct consequence of the ambiguity regulation and interpretation of the right to environmental protection is that it cannot be protected effectively, frequently (Renucci, 2019).

\section{CONTENT OF THE LAW}

Any individual has a right to live in satisfactory living conditions, strengthen environment quality to allow them to live in dignity and welfare (Sudre et al, 2019). As well, any individual has a solemn duty to protect and improve the environment for present and future generations (Wachsmann, P., 2019).

The right to a healthy environment is regulated in parallel with the obligation to protect it. There is, thus, the perception that the individual is both victim and polluter of the environment which involves that an individual responsibility deals with collective concerns. Therefore, environmental law is the interface between the general interest of environmental protection and defense interests of subjective quality of the environment (Andriantsimbazovina et al., 2008).

It may also arise from the dynamic and constructive interpretation (Renucci, 2019) of the civil rights provided by European Convention on Human Rights or social rights enumerated in European Social Charter.

Taking into consideration the social value affected by a right violation, it may be done an analysis of the relation between right to a healthy environment and other fundamental rights. All the rights may be organized in different group which underlines the main effects of the infringement of the right studied in current paper.

\section{Physical harms}

\subsection{Right to life}

Situations such as daughters' sickness with leukemia caused by the earlier exposure of the father with military career to nuclear testing, despite of dismissing the complaint because its unproven causality ${ }^{11}$ or killing of 39 people due to the explosion of a communal pipeline even they were living illegally around $\mathrm{it}^{12}$ are situations in which the State has had the obligation to guarantee the right to life even in cases of professional experiments and hazardous industrial activities in nature. The relevant fact is that the causes of death must not result directly from the acts of State agents. Subsequently, right's infringement requires compulsory an

${ }^{11}$ ECHR, LCB v. United Kingdom, Application No 23413/94, Judgment of June 9, 1998

${ }^{12}$ ECHR, Öneryıldiz v. Turkey, Application No. 48939/99, Judgment of November 30, 2004; 
independent and impartial investigation in order to determine the causes and responsibilities.

\subsection{The prohibition of inhuman and degrading treatment}

Living in a highly polluted aria and having health aftermaths ${ }^{13}$ may be considered degrading treatment if it has a certain level of gravity. Consequently, States should take appropriate measures to eliminate the causes of poor health reducing or even eliminating all forms of pollution ${ }^{14}$ or other aggressive activities affecting the health of the people ${ }^{15}$.

\section{Physical and emotional harms}

\subsection{The right to private and family life}

Situations such as underground water pollution by discharges from a public fountain ${ }^{16}$, noise made by the activity of an airport ${ }^{17}$, emanations of a waste water purification and waste treatment pestilential odors ${ }^{18}$, high-voltage power line crossing private lands ${ }^{19}$ are qualified as environmental damages which can affect a person's well-being and to deprive him/her of the opportunity to actually enjoy a normal private and family life. As well, emissions of harmful chemical industry have a direct impact on the right to respect for private and family life ${ }^{20}$. Sufficiently close link between the environment and Article $8^{21}$ exists, too, in the following case: a disco neighborhood. Domicile is determined taking into account the physical space where is unfolding the private and family life; so, it is important not only material or bodily harm, but also immaterial one such as noise, emissions, odors and other interferences ${ }^{22}$.

\footnotetext{
${ }^{13}$ ECHR, Lopez Ostra v. Spain, Application No. 16798/90, Judgment of December 9, 1994

14 ECHR, Cordella and others v. Italy, Applications nos. 54414/13 and 54264/15, Judgment of January 24, 2019

15 ECHR, Florea v. Romania, Application no. 37186/03, Judgment of September 14, 2010; Elefteriadis v. Romania, Application no 38427/05, Judgment of January 25, 2011

${ }^{16}$ ECHR, Zander v. Sweden, Application No. 14282/88, Judgment of November 25, 1993

17 ECHR, Powell and Rayner v. The United Kingdom, Application No. 9310/81, Judgment of February 21, 1990.

ECHR, Hatton v. The United Kingdom, Application no. 36022/97, Judgment of July 8, 2003

${ }^{18}$ ECHR, Lopez Ostra v. Spain, Application No. 16798/90, Judgment of December 9, 1994

${ }^{19}$ ECHR, Calancea and others v. Rep. Moldova, Application no. 50425/11, Judgment of February 6, 2018

${ }^{20}$ ECHR, Guerra and Others v. Italy, Application No. 14967/89, Judgment of February 19,1998

${ }^{21}$ ECHR, Taskin and Others v. Turkey, Application No. 46117/99, Judgment of May 27, 2008;

ECHR, Moreno Gómez v. Spain, Application No. 4143/02, Judgment of November 16, 2004

${ }^{22}$ ECHR, Giacomelli v. Italia, Application No. 59909/00, Judgment of October 19, 2006
} 
In this kind of situations appear to be relevant the negative obligation of the State to refrain from arbitrary interference with the right to a healthy environment and substantial positive obligations: protection - authorities should cease or reduce pollution - and information of the population - right to be informed about the risks of serious pollution year caused by a dangerous activity ${ }^{23}$ - , taking measures to protect individuals against their attacks upon environment, which include interrelations and private sector activities (Sudre et al, 2019; Renucci, 2019).

In respect of procedural obligations, it is necessary for the State to make surveys and studies in which have to be analyzed the views of those involved ${ }^{24}$, to assure access to their conclusions for the public and to guarantee the possibility to be introduced complaints against them ${ }^{25}$.

Nevertheless, these obligations are not absolute. It should be a fair balance between the interests of the individual and interests of the community as a whole ${ }^{26}$ : For example, nine urban policies can justify limitation of the rights of several individuals ${ }^{27}$ or it has to be balanced the interest of nocturnal use of an airport and a private interest of living in that aria (Renucci, 2019).

Essential is that the violations must have a high degree of seriousness ${ }^{28}$ : adverse consequences on health.

As well, environmental human rights are a general policy. Despite extended discretion over the concrete facts of a case - Heathrow Hatton is considered as having reasonable overall noise - living in pollution is appreciated that constitutes a moral damage ${ }^{29}$, even Strasbourg Court's position has fluctuated in recognition of the possibility of obtaining them ${ }^{30}$. Thus, in the first case related to a hazardous installation, the Court rejected the possibility to invoke Article 6 because of the fragile link and remote consequences. In another case ${ }^{31}$, based on the civil side, the Court admitted to grant moral compensations highlighting the need for health and environmental protection Turkish law (Sudre et al, 2019).

Besides, in national legislation, rarely is retained the requirement to assure access to justice in matters of environment. For example, the right to live in a

\footnotetext{
${ }^{23}$ ECHR, Guerra and Others v. Italy, Application No. 14967/89, Judgment of February 19,1998

${ }^{24}$ ECHR, Hatton v. The United Kingdom, Application no. 36022/97, Judgment of July 8, 2003

${ }^{25}$ ECHR, Taskin and Others v. Turkey, Application No. 46117/99, Judgment of May 27, 2008

${ }^{26}$ ECHR, Lopez Ostra v. Spain, Application No. 16798/90, Judgment of December 9, 1994

${ }^{27}$ ECHR, Chapman v. United Britanie, Application No. 27238/95, Judgment of January 18, 2001

${ }^{28}$ ECHR, Lopez Ostra v. Spain, Application No. 16798/90, Judgment of December 9, 1994

${ }^{29}$ ECHR, Zander v. Sweden, Application No. 14282/88, Judgment of November 25, 1993

${ }^{30}$ ECHR, Balmer Schafroth and Others v. Switzerland, Application No. 22110/93 , Judgment of August 26, 1997;

ECHR, Athanassouglou and Others v. Switzerland, Application No 27644/95,Judgment April 6, 2000

${ }^{31}$ ECHR, Okyay and Others v. Turkey, Application No. 36220/97, Judgment of July 12, 2005

ECHR, Taskin and Others v. Turkey, Application No. 46117/99, Judgment of May 27, 2008
} 
healthy and balanced environment recognized by French law is a civil entitlement. Just use water fountain dating preventing pollution is a civil right ${ }^{32}$. The right to build on own land might be appreciated as opposition to urban development ${ }^{33}$.

There must be a direct link between environmental problems and civil law invoked. Because Article 6 may be invoked in the case of environmental issues is necessary as a civil right to be questioned. And the application of Article 13 ECHR is reduced as explicit material enshrines a right to protection of the environment, but on the basis of obligations arising from the exercise of Articles 2 and 1 of Protocol 1 ECHR has reconsidered the perspective of the right to effective remedy environmental ${ }^{34}$. The threat must be serious, precise and imminent danger not global (Renucci, 2019).

\subsection{Freedom of thought, conscience, religion.}

Building a house of prayer is considered incompatible with planning regulations and zoning ${ }^{35}$.

\subsection{Freedom of expression.}

Given the lack of procedural fairness and the disproportionate award of damages, and whether the interference with the individuals' freedom of expression - not journalists - had been "necessary in a democratic society", it had been appreciated that "in a democratic society even small and informal campaign groups had to be able to carry on their activities effectively. There existed a strong public interest in enabling such groups and individuals outside the mainstream to contribute to the public debate by disseminating information and ideas on matters of general public interest such as health and the environment" ${ }^{36}$.

\section{Material harms}

\subsection{Right to property}

In principle, there is no guarantee a right to maintain the property in a pleasant environment. Recognition of the use of property in the general interest changes everything. Certain activities can have serious consequences on the value of the property, even to make unsalable ${ }^{37}$. The benefit of clean water is a proprietary ${ }^{38}$.

\footnotetext{
32 ECHR, Zander v. Sweden, Application No. 14282/88, Judgment of November 25, 1993

${ }^{33}$ ECHR, Allan Jacobsson v. Sweden, Application No 16970/90, Judgment of February 19, 2008

${ }^{34}$ ECHR, Öneryıldız v. Turkey, Application No. 48939/99, Judgment of November 30, 2004; ECHR, Fotopoulou v. Greece, Application No. 66725/01, Judgment of November 18, 2004

${ }^{35}$ ECHR, Vergos v. Greece, Application No 65501/01, Judgment of June 24, 2004

${ }^{36} \mathrm{ECHR}$, Steel and Morris v. The United Kingdom, Application no. 68416/01, Judgment February 15, 2005; Vides Aizsardzības Klubs v. Latvia, Application no. 57829/00, Judgment May 27, 2004

${ }^{37}$ ECHR, Taskin and Others v. Turkey, Application No. 46117/99, Judgment of May 27, 2008

${ }^{38}$ ECHR, Zander v. Sweden, Application No. 14282/88, Judgment of November 25, 1993
} 
Environmental imperatives can justify restrictions on the right to respect individual property ${ }^{39}$. The right to receive and impart information ${ }^{40}$; this right with application to environmental issues is a major concern: it is of general interest as individuals and groups to contribute to the debate public. The restriction is accepted if the measures are proportionate to the legitimate aim pursued and the right balance between individual and collective interests ${ }^{41}$. There is a general obligation to state its own initiative ${ }^{42}$.

\section{CONCLUSIONS}

The protection of the right to a healthy environment, no matter if it is considered an individual or a collective right, has to be assured effectively by the bodies of the supranational and national entities. The case law of European and national courts on environmental issues is continuously fluctuating (Rainey et al, 2017).

Beyond these two general remarks remains as general conclusion of this study on environmental protection that the focus is currently on the measures which transpose preventive and precautionary principles essential for a sustainable development, fundamental concept for future generations (Andriantsimbazovina et al., 2008).

\section{References}

Renucci J. F., Droit européen des droits de l'homme. Droits et libertes fondamentaux garanti par la Convention europeene de droits de l'homme, 8éme édition, LGDJ, 2019.

Sudre F., Milano Laure, Surrel Hélène, Droit européen et international des droits de $l$ homme, édition 14éme mise à jour, Presses Universitaires de France, 2019, 〈hal02088943>

Chalmers D., Davies G., Monti G., European Union Law. Text and Materials. Fourth Edition, Cambridge University Press, 2019

Wachsmann P., Les droits de l'homme, 6éme édition, Dalloz, 2018.

Rainey Bernadette, Wicks Elisabeth, Ovey Clare (Jacobs, White and Ovey), The European Convention on Human Rights. $7^{\text {th }}$ Edition, Oxford University Press, 2017, http://orca.cf.ac.uk/id/eprint/106327

${ }^{39}$ ECHR, Pine Valley Develpments Ltd and Others v. Irlanda, Application no. 12742/87, Judgment of November 29, 1991

${ }^{40}$ ECHR, Steel and Morris v. The United Kingdom, Application No 68416/01 Judgment February 15, 2005

${ }^{41}$ ECHR, Vides Aizsardzibas Klub c. Letonia, Application No, Judgment of May 52004

${ }^{42}$ ECHR, Guerra and Others v. Italy, Application No. 14967/89, Judgment of February 19,1998 
Favoreu L., Tremeau J., Gaïa P., Droit des libertés fondamentales, 7éme édition, Dalloz, 2015.

Craig P., De Búrca Gráinne, The Evolution of European Union Law. Texts, Cases and Materials. Sixth Edition, Oxford University Press, 2015.

Lenaerts K., Maselis I., Gutman Kathleen, European Union Procedural Law, Oxford University Press, 2014

Lenaerts K., Van Nuffel P., Bray R., European Union Law, London Sweet and Maxwell, 2011.

Andriantsimbazovina J., Gaudin Hélène, Marguénaud J.P., Rials S., Sudre F., Dictionnaire des droits de l'homme, Presses Universitaires de France, 2008.

Dutertre G., Key case - law extracts. European Court of Human Rights, Publication of Council of Europe, 2004.

\section{Webgraphy:}

MANUAL ON HUMAN RIGHTS AND THE ENVIRONMENT:

https://www.echr.coe.int/Documents/Pub_coe_Environment_2012_ENG.pdf

Factsheet - Environment and the ECHR:

https://www.echr.coe.int/Documents/FS_Environment_ENG.pdf

(C) 2020 by the authors. Licensee UAIC, Iasi, Romania. This article is an open access article distributed under the terms and conditions of the Creative Commons Attribution (CC BY-NC-ND) license (https://creativecommons.org/licenses/by-nc-nd/4.0). 